\title{
EMPATHY AS THE FOUNDATION OF THE SOCIAL SCIENCES AND OF SOCIAL LIFE: \\ a reading of Husserl's phenomenology of transcendental intersubjectivity
}

Frédéric Vandenberghe*

\begin{abstract}
Starting with an overview of possible solutions to the problem of social order, the author presents a non-acritical reconstruction of Edmund Husserl's transcendental phenomenology of intersubjectivity as a sympathetic alternative to Habermas's theory of communicative action. By means of a detailed analysis of the concept of empathy (Einfühlung), he shows that Husserl's phenomenology of intersubjectivity offers a triple foundation of the sciences. As a warrant of the objectivity of the world, it grounds the natural sciences; as a presupposition of sociality, it founds the social sciences; as mediated by culture, it grounds the social sciences as human sciences.
\end{abstract}

Keywords: social order, empathy, phenomenology, Husserl, Habermas.

\section{Social theory and the problem of order}

If philosophy distinguishes itself from the human sciences by the fact that it is 'without object' (Althusser), and if we assume that social theory is not just 'social philosophy for failed philosophers', then we may start to wonder what its object actually is. As an entry, and a pretext, to the theme of empathy, I would like to suggest that social theory deals with many objects, including 'hairy ones' (Latour), * Senior Researcher at the University for Humanist Studies in the Netherlands and visiting
professor at the Universidade de Brasília (Winter 2003).

Artigo recebido em 9 maio 2003; aprovado em 30 ago. 2003. 
but that this plurality can nevertheless be reduced to one deceptively simple question: 'How is society possible?' 1 As a matter of fact, this problem of social order is always already solved in everyday life. Even in prisons, favellas, or civil wars, Ego and Alter are in principle, if not in practice, able to co-ordinate their actions one way or another, and thus to avoid the utter chaos of absolute unpredictability. In this sense, the question of social order serves a merely heuristic function. It aims to reflexively uncover the conditions of possibility of social life as such, and correlatively, of the social sciences themselves.

Looking back at the long history of the social sciences, from Plato to NATO, we can distinguish two ideal typical solutions to the problem of social order which, broadly speaking, correspond to the distinction sociologists usually make between theories of action on the one hand and of systems on the other. Either the actions of Ego and Alter are co-ordinated in a systemic way, that is they are coordinated through the system, or, alternatively, they are co-ordinated by the actors themselves. ${ }^{2}$ In the first case ('systemic integration'), the co-ordination of the actions is not intended as such by the actors. It is the unintended result of the interlocking of the consequences of their action. The co-ordination thus happens, as Marx says, a tergo, behind the back of the individuals. Following Halévie, whose history of utilitarianism significantly influenced Talcott Parsons, we can distinguish two systemic solutions to the problem of social order, namely the political and the economic one. ${ }^{3}$ In the political solution, the problem is solved through the 'artificial identification' of the individual interests with the general interest through political constraint. Hobbes' Leviathan, Bentham's Panopticon and Carl Schmitt's advocating of a strong state can serve as examples of this authoritarian tradition of thought. In the economic solution, the problem is solved through the 'natural identification' of interests through economic constraints. Mandeville's Fable of the Bees, Adam Smith's 'invisible hand' and Hayek's theory of the market as a 'catallaxy' are examples of this liberal tradition of thought. In his critique of commodity fetishism, Marx has shown that this solution only represents an economic variant of Hobbes' Leviathan. The political constraints of the state are merely replaced by the economic constraints of the pseudo-natural laws of the market. 
The problem with systemic solutions is that they can only conceive of the social order as a constraining one that is imposed on the actors a tergo and post actum. From a metatheoretical perspective that analyses the most general presuppositions of sociology (What kind of action is presupposed? How are social structures conceived? What is the relation between agency and structure), the problem appears to be linked to the nature of action that is foregrounded. Action is either conceived in purposively rational (Zweckrational) or strategic terms. ${ }^{4}$ It is only if a non-strategic conception of action is introduced that we can conceive of a social order that is not imposed from above or without, but is in line with the intentions of the actors themselves. Thus, we pass from 'systemic' to 'social integration'. The co-ordination of action is a fronte; it is intentionally pursued and effectively accomplished by the actors themselves. It is not imposed on them from without, but is the immanent result of the intentional interlocking of their mutual perspectives.

Simplifying once again the history of sociological ideas for didactic purposes, we can distinguish three 'social' solutions that introduce such 'non-strategic' elements in the picture. ${ }^{5}$

1) In the normative solution, the problem of order is solved through the internalisation of norms and values. Durkheim's conception of moral facts, Freud's analysis of the internalisation of norms and their synthesis in Talcott Parsons' structural functionalism are examples of this normative tradition of social theorising. Here the underlying idea is that actions are co-ordinated through the institutionalisation of norms and values. It is because people share certain institutionalised values and norms, that the problem of the 'double contingency of action' (ParsonsLuhmann), is overcome and that the complementarity of expectations can be assured. To take an example that Parsons has worked out at length in The Social System, the patient knows how to behave when he goes to the doctor, because he has internalised the expectations that are associated with the role of the doctor and the patient. 
2) In the rationalistic solution, the problem of social order is solved through the constraint of Reason. Kant's theory of practical reason, George Herbert Mead's conception of the General Other and Habermas's theory of communicative action serve as examples of this tradition of the Enlightenment. The interlocking of perspectives and the co-ordination of actions is here accomplished not so much through the internalisation of traditional norms and values, as is the case with Parsons, but by means of a rational and critical discussion of the normative, the cognitive and the expressive validity claims that are implicit in every speech act and that can be explicitly thematised in case a spontaneous agreement is not reached and enacted in practice. This communicative solution improves on the preceding one in so far as it breaks with the 'traditionalism' of the former and is thus better suited for highly individualistic societies like ours in which individuals are increasingly 'set free' (freigesetzt, to quote Beck) from the constraints of the normative institutions of the past and have to reflexively cobble together their narrative identity on the basis of a self-chosen set of values and norms.

3) Although I tend to agree with Habermas' communicative solution to the problem of social order and think that it allows us to conceptualise how individuals can live with anomie without however abandoning the project of individual and collective autonomy, I would like to try to build a phenomenological storey under his communicative revision of historical materialism in order to make it more contextual and concrete and, thus, less formal. A series of 'epistemological obstacles' have so far prevented a fruitful exchange of ideas between phenomenologists and critical theorists of the second generation. Instead of seriously dealing with the phenomenological movement, Habermas and Apel have both written it off (after a short-lived infatuation with Heidegger) on the grounds that phenomenology remains hopelessly entrapped in 
subjectivism and that it can only overcome its monological bias by taking the 'linguistic turn'. ${ }^{6}$ Habermas and Apel may be right, but in this article I would like to explore, through a reading of Edmund Husserl's phenomenology of intersubjectivity, how a critical theory of communication could be phenomenologically grounded in such a way that it would be able to describe in detail how intersubjectivity is actually established by the actors themselves and, once this is done and we move up from intersubjectivity to interaction, to analyse how a common world is progressively constituted through intentional acts of communication.

Without inquiring into the prepredicative and prelinguistic bases of linguistic intersubjectivity, Habermas and Apel take intersubjectivity as given. Instead of taking the 'inter' of intersubjectivity seriously and analyse how Ego and Alter, each separately, yet mediated through the bodily presence of the Other, establish the interconnection of their minds, critical theorists take intersubjectivity for granted and treat it as the unquestioned stepping stone of their (quasi-)transcendental analyses of the 'unlimited community of communication' which every speech act allegedly presupposes as its unquestionable telos. From the standpoint of transcendental phenomenology, this position is unwarranted or 'unfounded' in so far as the constitution of the 'community of communication' presupposes that Ego and Alter are able to constitute each other as Alter Ego's in the first place. Intersubjectivity is not a given, but the result of a process of intentional constitution by the actors themselves. Indeed, according to Husserl, one cannot investigate the realm of social interactions without analysing how the Other is constituted as an Alter Ego through empathy (Einfühlung), that is through the apperception of the body of the other as a living body. Thanks to this foregrounding of the living body and of the experience of the flesh, as first analysed by Husserl and further developed by Merleau-Ponty and Waldenfels, phenomenology is also able to correct an important oversight in Habermas' theory of communicative action. In the grand scheme of things of Habermas, there's hardly any place for bodies and bodily feelings. Given that he does not take into account 
the incarnated nature of human action, everything happens as if minds could directly communicate with each other, without the mediation of the body and without the intervention of emotions. It is true that Husserl's approach is as cognitivistic as Habermas's and that we can hardly rely on him to theorise emotions. Yet, thanks to his insistence on empathy and the emotive connotations that empathy (Einfühlung, Mitgefühl) evokes, we can already vaguely sense that Habermas not only neglects the body, but also the motivational contributions of moral sentiments to successful and failed attempts at communication.

Bringing some of this points together, I would like to explore and try to develop a coherent and systematic account of a fourth solution to the problem of social order, namely one which insists on empathy and sympathy, conceived as a foundation both of social life and of the social sciences. In this context, I will analyse in depth Husserl's phenomenological account of transcendental intersubjectivity, Max Scheler's theory of sympathy, Adam Smith's theory of moral sentiments and Erving Goffman's analysis of the interaction order. The horizon of this research is thus constituted by a social theory of affective action which remains true to the project of Enlightenment but which no longer accepts its anti-phenomenological prejudices. $^{7}$

\section{Enter Husserl}

During his whole life, Edmund Husserl was only interested in one philosophical issue: The Letztbegründung, or the securing of an absolute and ultimate foundation of all possible knowledge. He was not interested in Sociology as such, and, in fact, it is not even clear how one could immediately use his analysis of transcendental consciousness for sociological purposes. And yet, I think that his phenomenological analysis of intersubjectivity might be of some relevance to the question of the social order. The following analysis of Husserl's phenomenology of intersubjectivity is only tentative. As suits a real beginner - and Husserl himself reminds us that in phenomenology everybody is a "true beginner" (Hua V, 161) ${ }^{8}$ 
I have decided to avoid any pre-judgements. I'll try to present a "charitable" reconstruction of Husserl's phenomenology of intersubjectivity and keep my doubts about the possibility of a transcendental sociology and my critical questions regarding his egological attempt to overcome solipsism for myself. Reading Husserl is certainly challenging and rewarding, because his thought is rigorous and helps us to conceive of the social sciences as human sciences (Geisteswissenschaften), grounded on non-naturalistic foundations, but it is frustrating at the same time, because if Husserl is a tremendous analyst, he's unfortunately not that great when it comes to presenting his own thought in a synthetic and systematic way. Moreover, he could only think while writing, with the result that he left us more then 40.000 dense pages, written in stenography, and in which, at the end, he himself couldn't find his way anymore. Thus, the challenge is to try to see the wood through the trees - and in phenomenology, what really matters are the trees.

The phenomenological project and the problem of solipsism

Literally, phenomenology is the study of phenomena. More precisely, it is a careful and detailed analytic description of phenomena. A phenomenon is anything that appears or presents itself reflexively to the stream of consciousness as it is ordinarily experienced (seen, heard, touched, felt, etc., in actual experience, in memory, in anticipation, or even as fantasised) by the individual consciousness - e.g. the chair here, the inkpot on my desk, the blossoming apple-tree in the garden, but also the memory of the first day of my arrival on the Plano Piloto, my dislike of my neighbour's dog or my loving fondness of his wife. ${ }^{9}$ So, anything which appears in and gives itself reflexively to the stream of immanent consciousness is a legitimate area of phenomenological analysis, because phenomenology is nothing else but the careful analytic detailed description of the essential (eidetic) structures of the experience of phenomena, of the ways (perception, fantasy, memory, etc.), the modes (actuality, potentiality, receptivity, spontaneity) and the doxic modifications (negation, neutralisation, doubt, etc.) in which the things 
'themselves' appear to consciousness. ${ }^{10}$ As such, phenomenology is not a theory, but it is a philosophical method for analysing how things appear to, and are thus intentionally constituted as, meaningful objects by consciousness. ${ }^{11}$

Phenomenology conceives of itself as prima philosophia (Erste Philosophie I, Hua VII, 13-14). It wants to be a "rigorous science" (Hua XXV, 3-62) which founds or grounds knowledge on absolute, primary and indubitable foundations. Following Descartes' (first and second) Meditations, Husserl finds this foundation in the apodicticity of the Ego cogito. However, unlike Descartes, who attributed a mundane status to the Ego and deduced the rest of the world from it, Husserl withdraws from the mundane to the transcendental sphere of the pure Ego and conceives of this sphere as his "infinite field of labour" (Hua XXV, 62). In order to get at this transcendental sphere of pure consciousness, he proposes the two methodological tricks of the epoché and the phenomenological reduction. ${ }^{12}$ To effectuate the epoché means 'putting between brackets' (in the mathematical sense), in this case putting the existence of the world, which is always naively assumed in the natural attitude, between brackets and taking it as a pure phenomenon, as a pure correlate of intentional consciousness. The reduction is always a reduction to..., in this case reduction of transcendence (the thing out there) to immanence (the thing as cogitatum), to the constituting activities of the pure Ego. Anyway, by effectuating the epoché we loose the world, so to speak, but we gain access to the infinite realm of pure consciousness. What remains after the reduction as a "phenomenological residuum" (Ideen I, 59, 94 ) is "the world", the world between brackets, not the world out there, but the world as an object of consciousness, understood as an intended object of pure constituting consciousness.

The "world", that is the world as perceived or experienced in any other way by me, is only and has only meaning insofar as it is constituted by me as an object of consciousness. To that extent Husserl's transcendental idealism is an almost pure form of egology. Whatever is, is and can only be insofar as it relates to the constituting activities of my pure Ego. The world is dependent on me in a sense in 
which I am not dependent on the world. But if the world is mine, how can I then be sure of its objectivity? I can only be sure of it if my world is the same as the world of the others. The objectivity of the world requires and presupposes transcendental intersubjectivity. In his summary of the Cartesian Meditations, Husserl says as much: "Transcendental intersubjectivity is the transcendental basis of the constitution of the objective world, and of the intersubjective value of ideal objectivities" (Hua I, 200).

The passage from transcendental subjectivity to transcendental intersubjectivity is thus spurred by the problem of the objectivity of the world. It presupposes that the temptation of solipsism can be overcome. ${ }^{13}$ That Husserl is not a solipsist, and that notwithstanding the fact that he starts from the "philosophical loneliness" of the transcendental Ego (Krisis, Hua VI, 188), he can account for the existence of Other Ego's; even more, that there's an internal progression in his thought from a transcendental egology to a transcendental sociology or, more precisely, to a "sociological transcendental philosophy" (Hua IX, 539; Hua XI, 220), that is what I want to show in the following analysis of Husserl's phenomenology of transcendental intersubjectivity. ${ }^{14}$

\section{Transcendental intersubjectivity and empathy}

But first, what is transcendental intersubjectivity? Because of its misleading connotations, it should be stressed from the outset that it does not point to a constituting collectivity (a 'transcendental We'), but to the way in which the transcendental Ego has access to the constituting activities of another transcendental Ego. The central question of transcendental intersubjectivity is thus: How can an absolute and transcendental Ego experience or constitute another absolute and transcendental Ego? How can a constituting consciousness experience another constituting consciousness? How can I have access to the mind of the Other? ${ }^{15}$ According to Husserl, we can have access to other minds through empathy. For sure, we cannot have direct access to the mind and to the feeling states of the 
Other, because if we could, the Other would not be the Other but she would be identical to me. The problem really consists in gaining access to the mind of the Other, without reducing the Other Ego to myself. As he says in the Cartesian Meditations: "If I would have direct access to what essentially belongs to the Other, then he would just be a moment of my being and, at the end, he and I would just be one" (Hua I, 139). The Other Ego has to be constituted by me, but precisely as an Alter Ego, that is as an Ego who is herself a constituting Ego. Husserl advances a specific way of constituting the Other which satisfies the criterion of his originality. Following Theodor Lipps, he calls it empathy (Einfühlung). ${ }^{16}$ The main assumption is that the states of mind of the Other are really her states of mind, and not mine, but that I can have indirectly access to them through the apperception of her body (Körper) as a living body (Leib).

a) Reduction to the sphere of ownness

Husserl starts his analysis of transcendental intersubjectivity in a roundabout way. He transforms the objection of solipsism into an argument in favour of intersubjectivity. Within the phenomenological reduction, he proposes another reduction - the reduction to 'primordiality' or to the 'sphere of ownness'. This reduction is really an abstraction. Indeed, it summons us to make abstraction of all references to the consciousness of Others and thus to the existence of Others. What remains after this reduction is "nature as such", not the nature of the natural sciences, but so to speak "natural nature", nature which is stripped of all its value - and meaning - predicates. In this reduced nature, there's only one body, my body, my living body (Leib).

My living body is not simply a material thing among other material things. My body is an animated thing, it is a strange complexion of nature and soul. It is not so much subject to the laws of nature, as material things are, but it has its own characteristics (cfr. Ideen II, Hua IV, 143 sq.). 17

1) My body is a sensing body, it is a tactile body. It is not so much a thing I see (after all, I can't see the back of my own body) as a thing I feel. When I rub my left hand on my right hand, I feel myself, and doubly so: as an active touching body, and as a touched body. 
2) My body is also a point of orientation. It is, as Husserl says, the "zero-point of reference" from which I perceive all things. Whatever is and whatever appears in my environment is related in terms of nearness and distance to my body.

3) My body is a willing body, it is the practical organ of my will. It can move, or better I, "the hegemonikon of the body" (Hua IX, 197), can move it, and by moving it, I can intervene in the world. The world is always already there, it is always passively given, but if I want, I can actively intervene in it.

b) Empathy or the apperception of the body of the other as a living body

But now - and here we pass for the first time from the solipsistic to the intersubjective sphere - another body appears in my visual sphere. I see the Other as a body, and yet the Other is not just a material body, but a living body: "The body, the living body of the other, is the first intersubjective thing" (Hua XIV, 110). This body is a body like mine and is analogous to my body. By an act of imagination, I put myself in the place of the other. Her body is there where I was a while ago, but where I am not anymore. It sees what I saw, but given that it is there, while I am here, I cannot see what it sees. However, given that her body is analogous to mine, I almost automatically associate the characteristics of a living body with this material body (the so-called "copulation" or Paarung, cfr. Hua I, 141-143). The body of the Other appears like a thing but it is not a thing. And in the same way as signpost points towards a direction or a word towards its meaning, the body of the Other points towards her mind. Husserl says that I "apperceive" (or "appresent") the material body of the Other as a living body. By apperception (or appresentation) he means to say that I perceive something which I cannot see. The same happens when I see a house or when I hear a clock ticking. I see only the front of the house, but I apperceive the back. When I go round the house I can see its back. I hear only the ticking of a clock, but when I look around I'll find a clock, and I'll perceive it in its original presence. The same can never happen with the apperception of the Other. I can never perceive in the original mode what the Other perceives or feels in the 
original mode. "Appräsenz”, says Husserl, is not "Urpräsenz" (Ideen II, Hua IV, 199). I cannot have the experiences of the Other in the original mode, but I can somehow vicariously experience them like her. This is exactly what empathy is about. If I have direct access to myself through experience of my living body, and through reflection on this experience, I have indirect access to the Other by means of the apperception of the mind through the perception of his or her body. It is thus through empathy that I posit the consciousness of the other. In one of the 1500 pages of the three volumes on the phenomenology of intersubjectivity, Husserl says that empathy creates "the first real transcendence. Here a second stream of consciousness is co-given, not as a pure construction of my stream of consciousness, but as one which is indicated by his body. Here for the first time consciousness transcends itself" (Hua XIV, 8).

c) From transcendental intersubjectivity to the objectivity of the world

Consciousness transcends itself through empathy when I apperceive the body of the other as a living body. That means, of course, that I apperceive the other as another human being, as another constituting Ego, in brief as an Alter Ego. And as I apperceive the Other, I realize that she perceives me. I am aware of that, and as I am aware of that, I perceive myself as she perceives me. Taking the attitude of the Other, I objectify myself and, for the first time, I perceive myself as a material body. "The body of the Other is the first body which I experience as a physical thing. [...] Only mediately, through the roundabout way of the Other and possible Others, I learn to experience my own living body as a physical thing" (Hua XIII, 63). My living body perceives itself as a material body at the same time as I apperceive your material body as a living body. It now appears that this double perception of myself both as a living and as a material body was already presupposed by my apperception of your body as a living body. Because if I couldn't perceive myself as a material body, I couldn't apperceive your material body as a living body either. The Czech philosopher Jan Patocka marvellously summarises this accomplishment by saying that "the experience of the second person, 
the realisation of the you, presupposes the experience of one's self both in the first and the third person". ${ }^{18}$

In any case, when I perceive you in the second person, I realize that you perceive others too in the second person, and I recognise that there is a plurality of constituting transcendental Ego's. When I perceive myself in the third person, I realise that my body becomes a body among other bodies and the world becomes peopled by other bodies, which are like my body and which perceive the surrounding world as I perceive it. Thanks to empathy, I experience the world at least twice: "Once as experienced directly by me, the other time as experienced empathically, so to speak through the eyes of the others" (Hua XIV, 315). In this way, thanks to the Other Ego's, I become an Ego among other Ego's and the objectivity of the world is secured. Eventually, we rejoin the evidence which we had when we were in the "natural attitude", but the evidence that there are Others and that we live in a common world is now clear as an evidence which is understood: "The transcendent world, the human beings, their relations with me and with one another as human beings, their experiencing, thinking, working and creating together is not suspended, devalued or changed by my phenomenological meditation, but it is only understood ... and so is the communal activity of phenomenology, which understands itself as the meditative function of transcendental intersubjectivity" (Formale und transzendentale Logik, Hua XVII, 282).

\section{d) From transcendental intersubjectivity to society}

Given that phenomenology finishes where the objectivating sciences begin (Hua II, 58), Sociology takes off when and where the phenomenological account of transcendental intersubjectivity comes to its term. In principle, with the interconnection of minds, the coordination of actions that founds society, or as Simmel would say, that is society, has become a real possibility. With empathy, intersubjectivity is established, but intersubjectivity is not social interaction.19 We know that we are not alone in the world and that we share a common life-world. But intersubjectivity as such is only a precondition of social life. ${ }^{20}$ When I know that the Other apperceives 
me as a concrete human being, when she knows that I know and knows that I know that she knows, we are both aware of our mental interconnection. We are in spiritual contact, as Husserl says. But it is only when I address myself to you, when we enter into actual communication with one another that my actions can motivate your actions and yours mine, and that the higher unity of consciousness which constitutes the essence of social life is established.

According to Husserl, the elementary act of social life is communication. "Sociability constitutes itself through the specifically social, that is through communicative acts (Hua IV, 194). [...] Communicative acts are acts that are addressed to the Other, in which the Other is conscious as the one to whom I address myself; [acts] that include in themselves the consciousness that the Other understands what I say and that he will orient his behaviour to it, that he will reply with similar actions, and so on. Those are the acts that establish a higher unity of consciousness between the person and the person and which relate to the thing-world as a common world of judgement, will and valuations. In so far as the world has this relation, it has the character of a social world, a world endowed with spiritual meaning" (Hua XIII, 98).

Communication thus presupposes empathy, but it differs from empathy, on the one hand, because I can now have direct access to the mind of the other subject and, on the other hand, because I can act on her, with her, or against her. I have access to her mind, because the motivations that I impute to the other through empathising with her, can now be verbally confirmed by her. I can act on her and with her, because when I talk to her, she can respond to me, and we can come to an agreement to act together. In so far as Husserl continually stresses the importance of agreements for the co-ordination of actions, his descriptive sociology seems compatible with Habermas's theory of communicative action, even more it truly seems to anticipate it.21

Interpersonal communication is the elementary act of social life, and from there onwards we can progressively build up the larger interconnections of mind which lead from the dyad to the family, from the family to the community, from the community to the State 
and, from there, to intercultural communication among societies and humanity as such. The logical progression from the dyad to the worldsociety is only summarily worked out (cfr. Gemeingeist I and II in Hua XIV, 164-232). ${ }^{22}$ From a sociological standpoint, it seems very crude. Notwithstanding the usual association of phenomenology with individualism, it should be noted that Husserl adopts a holistic position and conceives of societies as "personalities of higher order" or "quasipersons", coming thereby dangerously close to Durkheim's sociologism and his metaphysics of the social mind. More interesting is his attempt to found the social sciences on personalistic foundations.

\section{Empathy as a foundation of and for the human sciences}

Empathy is not only the foundation of social life, it is also the foundation of the human sciences - the Geisteswissenschaften, as Husserl calls them following Dilthey, both of whom have been militating against the dominating naturalistic approaches of their time.

The starting point is that the method of access to the things has not to be determined by the sciences and the scientific experts but by the essential nature of the things themselves and their correlative modes of possible experience (Hua V, 22). Every empirical science forms a closed domain and its delimitation is a priori determined by the essence (eidos) of its objects. Husserl talks in that context about "regional" or "material ontologies" and he claims that they can be determined a priori by means of a procedure which he calls "eidetic variation". ${ }^{23}$ In the Ideen (II and III) he distinguishes three regional ontologies, namely material nature, animated nature and the spiritual world. In so far as they determine the ontological limits of the sciences and stipulate the possible variations of their objects, those regional ontologies offer the theoretical foundations of the empirical sciences. Here as elsewhere, the eidetic sciences that describe the essential and invariant structures of the ontological regions precede the empirical sciences and found them. As Husserl says repeatedly, "the science of pure possibilities precedes as such the sciences of realities and makes them possible as sciences" (Hua I, 106, cfr. also Hua V, 56 and 143). 
Any factual thing is contingent. It merely represents a possible instance among other possible instances of a more general essence which predetermines what the thing necessarily must be when it is to be a thing of a certain kind. We get to the essence of the factual thing if, by a process of imaginative variation, we arrive at a categorical determination of what makes that thing a thing of a given kind and in the absence of which it would no longer be a thing of that kind. We start, for instance, with the actual experience of a material thing, let's say a lump of gold. By an act of free imagination, I bring it into motion, I vary first its seize and then its colour, I change its composition and it turns into bronze or copper, now I fantasise it as a statue, then I fantasise it as a bike. Whatever variations I imagine, the thing remains a material thing, which means in that case that it has a spatial extension, that is subject to the laws of nature, and that I can subdivide it in the parts of which it is made up. But I cannot imagine that it starts dancing, because it belongs to the nature of a material thing that it doesn't move by itself, that it is not animated by a soul. Living bodies move by themselves, they are animated, they are incarnated souls. They belong to another regional ontology. It is a fundamental rule of eidetic analysis that "a fundamental concept of one region cannot be transformed by variation in another one" (EU, 435). Thus, the concepts of the region of the animated nature can not be reduced to those of material nature. The region of the animated body is at the intersection of the region of the material nature and the one of the spiritual world. It is dependent on a material substrate, but as living body, as a movable and willing body, it receives its impulses from the spiritual world. The passage from the region of the soul to the region of the spirit, which is build upon the former, is fluid, at least compared with the passage from the region of the thing to the region of the incarnated soul. In the spiritual world, we do not so much confront bodies as we encounter persons who express themselves and who encounter other persons and cultural objects in their environment. Persons are not subject to the causality of natural laws but to the causality of motivation (Ideen II, Hua IV, 172-208), and they are only motivated by things of which they are conscious. The things, the other persons, the culture and the social structures work on them, but only in the 
sense that they motivate the person to do something or to refrain from doing so. In order to understand what motivates a person, we have to understand him or her, and that is only possible through an act of empathy, by which we interpret his or her behaviour as a spiritual expression, that is as an expressive embodiment of their person which is mediated by their culture.

The point I want to stress here is that empathy is the key to the spiritual world. Through empathy we encounter the other as a person, as a human being, and not as a thing. In our everyday life, we spontaneously adopt what Husserl calls the "personalistic attitude" (Ideen II, Hua IV, 180 sq., Krisis, Hua VI, 294 sq.) When we live with each other, talk to each other and even when we quarrel with each other, we naturally apperceive each other as human beings. We spontaneously empathise when we try to understand each other. Even the things we encounter in our life-world, the houses, the cars, the gardens, the statues are not simply seen as things, but as practical or aesthetic things. The personalistic attitude is the natural attitude, the "naturalistic attitude" which reifies our environment is not natural, but it involves an artificial abstraction from the spiritual layer and a forceful reduction to its material substrate. In this sense, the personalistic attitude is primary. The naturalistic prejudice, which systematically reduces the regions of the soul and the spirit to the region of the material thing, must fall. Human beings are not just machines subject to the laws of nature. They act spontaneously and they endow their world with meaning. It is only when we adopt the personalistic attitude that we can understand their motivations and that we can have access to the spiritual world. The social sciences are human sciences. As such they rest on and presuppose empathy. Yet, it is not because empathy is a necessary and constitutive ingredient of the human sciences that the human sciences can be mere empathic sciences. $^{24}$

\section{Notas}

1 The neo-Kantian formulation comes from Simmel, (1992, p. 42-61). For a classic treatment of the Hobbesian problem of social order, see Parsons, 1937. 
2 On the opposition between theories of action and of systems, see Dawe (1970), on the corresponding forms of integration, see Lockwood (1964) and Archer (1996).

3 See Halévie (1972, chapter 1). There are at least two systemic solutions. If we follow Luhmann and the Luhmannisers, there are as many solutions as there are subsystems.

4 For a solid treatment of the metatheoretical logic of sociology, cf. Alexander (1982). See also Vandenberghe (1997, v. 1, p. 249-266; 2003).

5 It is enough to mention the work of Axel Honneth on recognition (1992), of Hans Joas on creativity (1992), of Patrick Pharo on social semantics (1997) and of Bruno Latour on interobjectivity (1994) to realize that there are in fact more than three non-systemic solutions to the problem of order.

6 Habermas (1988, p. 88-94; 1991, p.34-49) has only devoted a number of pages to Husserl. As far as I can see, Apel has silently expressed his fundamental objections to phenomenology by simply ignoring Husserl.

7 This was the original plan of a post-doctoral research project on empathy and sympathy that was funded by the Dutch CNPq but that I abandoned when I got seriously stuck in the Husserliana ('When you're in a pit, stop digging!').This article on Husserl is all that remains of the project. I humbly confess that I no longer believe in the possibility of a transcendental sociology and that I have serious doubts about empathy. In this text, which I offer to the reader as a piece of 'documentary evidence' of my youthful enthusiasm for phenomenology, I reconstruct Husserl's phenomenology of intersubjectivity without too much critique.

8 Apart from the references to Erfahrung und Urteil (abridged as EU), published by Felix Meiner Verlag, Hamburg, 1985 and the Logische Untersuchungen (abridged as LU I-III), republished in the 1980's by Max Niemeyer Verlag, Tübingen, all references are to the Husserliana (abridged as Hua), that is to the 36 volumes of Husserl's Gesammelte Werke which have appeared so far. The Hua have been edited since 1950 by the Husserl Archives in Leuven (Belgium) and published either by Martinus Nijhoff in The Hague or by Kluwer in Dordrecht.

9 Is is important to notice that the phenomenological analysis of consciousness is always reflexive analysis, that is analysis of consciousness as reflected upon by the Ego (e.g. being conscious of seeing a house) or by the meditating philosopher who reflects on the Ego and inhibits thereby any existential claims (being conscious of seeing a house and analysing the relation between the act and the object, without making 
any claims as to the existence of the house). Although the reflexive nature of phenomenology is already clearly announced in the Logische Untersuchungen (LU II/1, Einleitung), it is most clearly worked out in Phänomenologische Psychologie, Hua IX, §§ 28 sq. Moreover, one should also notice that Husserl's phenomenology is a transcendental phenomenology, that is a phenomenology which suspends the natural attitude of everyday life in order to analyse the a priori connection between thought and the thought object, thus in order to analyse how thought intentionally constitutes the object of thought, regardless of the ontological status of this object. The turn from a purely descriptive to a transcendental phenomenology is first accomplished in 1907 in the Ideen zu einer reine Phänomenologie (Hua II) and most clearly exposed in the the first volume of the Ideen I (Hua II) and the Cartesian Meditations (Hua I). For an excellent account of Husserl's intellectual development, see Biemel (1959).

10 Phenomenology is not and does not aim to be a factual science. It is an eidetic science that attempts to uncover a priori the essential "eternal" structures of all possible experiences of all possible worlds. This is most clearly spelled out in the Ideen I, Erster Abschnitt (Hua III) and the Ideen III (Hua V).

11 Properly speaking, phenomenology is an intentional analysis of the noeticnoematic structure of pure consciousness. By speaking of intentionality, Husserl is following, and at the same time amending, Brentano's theory of the "intentional in-existence" of the object according to which consciousness is always consciousness of... The implication of intentionality is that each cogitatio has two sides: the cogito or noesis, i.e. the act of experiencing, perceiving, feeling, etc., and the cogitatum or noema, i.e. the experienced, perceived, felt object. On intentionality, cfr. LU II/1, V (Uber intentionale Erlebnisse und ihre 'Gehalte') and Ideen I, dritter Abschnitt (Hua III).

12 By effectuating the 'phenomenological reduction', phenomenology takes a transcendental turn - which will be rejected by almost all of his followers, from Heidegger, Merleau-Ponty and Levinas to Ricoeur and Derrida. It should, however, be noticed that this turn, which Husserl presents as the most important breakthrough in the history of philosophy, can be accomplished in three ways. On the Cartesian way, which I follow here, the way through intentional psychology, and the way through the ontology of life-world, cfr. Boehm, R.: "Einleitung des Herausgebers", in Erste Philosophie, Zweiter Teil, Hua VIII, p. XI-XLIII and Kern (1962). 
13 "Solipsism consists in holding that the individual I ... with its subjective modifications, is all of reality, and that other I's of which one has representation have no more independent existence than persons in dreams; - or at least in admitting that it is impossible to demonstrate the contrary" - (cfr. Lalande, 1960, p. 1008).

14 The Fifth Meditation of the Cartesian Meditations (Hua I) is the main text in which Husserl presents his theory of transcendental intersubjectivity but in order to properly understand this difficult and condensed text, we will also have to rely on other writings: the three volumes on the Phenomenology of Intersubjectivity (Hua XIII-XV), the second volume of his Ideas towards a Pure Phenomenology and a Phenomenological Philosophy (Hua IV), the second volume of his First Philosophy (Hua VIII), his lectures on Phenomenological Psychology (Hua IX), and the posthumously published book on the Crisis of the European sciences (Hua VI).

15 Phrased as such, the problem of solipsism is equivalent to what AngloSaxon philosophers call the 'problem of other minds'. It results from the fact that one does not have sensory contact with other minds. Since persons comprise a union of body and mind, the natural place to look for sensory evidence of other minds is other bodies. Knowledge of other bodies does derive from the senses. But statements about other minds cannot be validly inferred from claims about other bodies - or can they?

16 In what follows, I assume but do not demonstrate the presence of an ontological moment in Husserl's analysis of transcendental intersubjectivity. The Other is the Other and his or her Alterity is safeguarded through empathy; his or her Alterity is thus not reduced to the monadic life of the Ego, thus to Ipseity, but precisely maintained as Alterity. For a useful analysis of Husserl's analysis of intersubjectivity that anticipates his later arguments on Identity and Ipseity and criticises Husserl's tendency to reduce the non-identity of the Other to the identity of the Self, see Ricoeur (1993, p. 75-109).

17 With some exaggeration, we could say that the whole philosophy of Merleau-Ponty, from his phenomenology of perception to his later thoughts on the chiasmus (but with the exception of his more political writings), is already contained in Husserl's Ideen II.

18 Patocka (1988, p. 120; 1992, p. 199).

19 Whether Husserl reduces sociality to intersubjectivity remains a moot point. See the introduction and the articles by Benoist and Descombes in Benoist and Karsenti (2001). 
20 This is made clear by Schütz's critique of Husserl's account of intersubjectivity. According to Schütz (1951), the concept of "transcendental we" is a kind of contradictio in terminis (a singulare tantum, as he says), because the transcendental stand necessarily implies a monadic one. From the mutual immanence of consciousness of Ego and Alter Ego, one cannot simply pass to their mutual interaction, as this involves a passage from a transcendental to a mundane sociology.

21 The only difference, of course, is that for Habermas interaction is primary, whereas for Husserl it is secundary, even to the point that one may really question whether a Monadic Sociology is possible in the first place. Once we have moved from the transcendental to the mundane level of analysis, however, the disagreement comes to a halt and we may regret that Habermas has not drawn on Husserl as much as Husserl has on Dilthey, who thought him that an individual psychology is really "nonsense" (Hua XIII, p. 472). See also Phänomenologische Psychologie, Hua IX, pp. 4 sq. and 354 sq.

22 See Toulemont (1962).

23 For a clarifying analysis of "regional ontologies", see Landgrebe (1963, p. 143-162).

24 On the limits of empathy, cfr. Kögler and Stueber (2000).

Resumo: Partindo de uma revisão de diversas soluções propostas para o problema da ordem social, o autor apresenta uma reconstrução não crítica da fenomenologia transcendental de Edmund Husserl como alternativa à teoria da ação comunicativa de Habermas. Através da análise detalhada do conceito de empatia (Einfühlung), ele mostra que a fenomenologia da intersubjetividade de Husserl oferece um triplo fundamento às Ciências Sociais. Como garantia de objetividade do mundo, ela a iguala às Ciências Naturais; como uma pressuposição de socialidade, ela as fundamenta Ciências Sociais, e por serem mediadas pela cultura, as converte em Ciências Humanas.

Palavras-chave: ordem social, empatia, fenomenologia, Husserl e Habermas.

Résumé: Passant en revue les diverses solutions proposées pour résoudre le problème de l'ordre social, l'auteur propose une reconstruction non critique de la phénoménologie de l'intersubjectivité transcendentale de Edmund Husserl comme une approche qui permet de corriger la théorie de l'agir communicationnel de Habermas. A partir 
d'une analyse serrée de l'empathie (Einfühlung), il montre que l'intersubjectivité intervient dans les écrits de Husserl d'abord comme fondement des sciences naturelles, car l'intersubjectivité assure l'objectivité du monde ; ensuite comme fondement des sciences sociales, car la socialité préppose l'intersubjectivité ; et, enfin, comme fondement des sciences humaines, car l'intersubjectivité donne accès au monde de la culture.

Mots-clés: ordre social, empathie, phénoménologie, Habermas, Husserl.

\section{Bibliography}

ALEXANDER, J. C. Theoretical Logic in Sociology. Berkeley: University of California Press, 1982. v.1: Positivism, presuppositions and controversies.

ARCHER, M. Social integration and system integration: developing the distinction. Sociology, v. 30, n. 4, p. 679-699, 1996.

BENOIST, J.; KARSENTI, B. (Eds.). Phénoménologie et sociologie. Paris: P.U.F., 2001.

BIEMEL, W. Die entscheidenden Phasen der Entfaltung von Husserls Philosophie. Zeitschrift für philosophische Forschung, v. 13, n. 2, p. 187-213, 1959.

DAWE, A. The two sociologies. British Journal of Sociology, v. 21, n. 2, p. 207-218, 1970.

HABERMAS, J. Nachmetaphysisches Denken. Frankfurt/M.: Suhrkamp, 1988.

. Texte und Kontexte. Frankfurt/M.: Suhrkamp, 1991.

HALÉVIE, E. The growth of philosophical radicalism. London: Faber, 1972. Chapter 1.

HONNETH, Axel. Kamp um Anerkennung. Frankfurt/M., Suhrkamp, 1992.

JOAS, Hans. Die Kreativität des Handelns. Frankfurt/M., Suhrkamp, 1992.

KERN, I. Die drei Wege zur transzendental-phänomenologischen Reduktion in der Philosophie Edmund Husserls. Tijdschrift voor Filosofie, 1962, 24, p. 303-349. 
KÖGLER, H.; STUEBER, K. (Eds.). Empathy and agency. the problem of understanding in the Human Sciences. Boulder: Westview Press, 2000.

LALANDE, A. Vocabulaire technique et critique de la philosophie. Paris: P.U.F., 1960.

LANDGREBE, L. Der Weg der Phänomenologie: das Problem einer ursprünglichen Erfahrung. Mohn: Gütersloh, 1963.

LATOUR, Bruno. Une sociologie sans objet? Remarques sur l'interobjectivité. Sociologie du travail. n. 4, p. 587-607, 1994.

LOCKWOOD, D. Social and Systems Integration. In: ZOLSCHAN, G.; HIRSCH, W. (Eds.). Explorations in social change. London: Routledge, 1964. p. 244-256.

PARSONS, T. The structure of social action. Glencoe: Free Press, 1937.

PATOCKA, J. Qu'est-ce que la phénoménologie? Grenoble: Jerome Millon, 1988.

. Introduction à la phénoménologie de Husserl. Grenoble: Jerome Millon, 1992.

PHARO, Patrick. Sociologie de l'esprit. Paris: P.U.F., 1997.

RICOEUR, P. A l'école de la phénoménologie. Paris: Vrin, 1993.

SCHÜTZ. Le Problème de l'intersubjectivité transcendentale chez Husserl.

In: Husserl. Paris: Minuit, 1951. p. 334-365. (Cahiers de Royaumont).

SIMMEL, G. Soziologie: Untersuchungen über die Formen der Vergesellschaftung, Frankfurt/M.: Suhrkamp, 1992.

TOULEMONT, R. L'essence de la société selon Husserl. Paris: P.U.F., 1962.

VANDENBERGHE, F. How is society possible? towards a metacritique of reification. Current Perspectives in Social Theory, JAI, Amsterdam, v. 22, p. 297-314, 2003.

. Une histoire critique de la sociologie allemande. Paris: Editions de la Découverte, 1997. v. 1, p. 249-266. 